\title{
Low concentrations of Rhodamine-6G selectively destroy tumor cells and improve survival of melanoma transplanted mice
}

\author{
M. KUTUSHOV ${ }^{1}$, O. GORELIK ${ }^{2, *}$ \\ ${ }^{1}$ Research \& Development Unit and ${ }^{2}$ Department of Internal Medicine "F", Assaf Harofeh Medical Center (affiliated to Sackler School of Medicine, \\ Tel Aviv University), Zerifin, Israel
}

*Correspondence: internal6@asaf.health.gov.il

Received September 14, 2012 / Accepted November 28, 2012

\begin{abstract}
Rhodamine-6G is a fluorescent dye binding to mitochondria, thus reducing the intact mitochondria number and inhibiting mitochondrial metabolic activity. Resultantly, the respiratory chain functioning becomes blocked, the cell "suffocated" and eventually destroyed. Unlike normal cells, malignant cells demonstrate a priori reduced mitochondrial numbers and aberrant metabolism. Therefore, a turning point might exist, when Rhodamine-induced loss of active mitochondria would selectively destroy malignant, but spare normal cells. Various malignant vs. non-malignant cell lines were cultured with Rhodamine-6G at different concentrations. In addition, C57Bl mice were implanted with B16-F10 melanoma and treated with Rhodamine$6 \mathrm{G}$ at different dosage/time regimens. Viability and proliferation of cultured tumor cells were time and dose-dependently inhibited, up to $90 \%$, by Rhodamine-6G, with profound histological signs of cell death. By contrast, inhibition of normal control cell proliferation hardly exceeded $15-17 \%$. Melanoma-transplanted mice receiving Rhodamine-6G demonstrated prolonged survival, improved clinical parameters, inhibited tumor growth and metastases count, compared to their untreated counterparts. Twice-a-week $10^{-6} \mathrm{M}$ Rhodamine-6G regimen yielded the most prominent results. We conclude that malignant, but not normal, cells are selectively destroyed by low doses of Rhodamine-6G. In vivo, such treatment selectively suppresses tumor progression and dissemination, thus improving prognosis. We suggest that selective anti-tumor properties of Rhodamine- $6 \mathrm{G}$ are based on unique physiologic differences in energy metabolism between malignant and normal cells. If found clinically relevant, low concentrations of Rhodamine-6G might be useful for replacing, or backing up, more aggressive nonselective chemotherapeutic compounds.
\end{abstract}

Key words: warburg effect, tumor, cell culture, melanoma, rhodamine-6G, mitochondria

Cancer cells are unique in their energy turnover. Unlike normal tissues that derive most of their energy by metabolizing the consumed sugar to carbon dioxide and water (the process taking place within mitochondria), tumors obtain as much as half of their ATP by metabolizing glucose directly to lactic acid. Normal tissues use the process of oxidative phosphorylation within mitochondria for $90 \%$ of ATP production, and only $10 \%$ is produced by glucose consumption. By contrast, in tumor cells this ratio is 50\%:50\% [1-3]. This unique pattern of tumor metabolism has been described in early thirties of the past century and has been recognized since then as Warburg effect [1-3]. Recent studies employing molecular biology and proteomic imaging technologies, explained the basics of Warburg effect $[4,5]$.

Rhodamine-6G is a fluorescent dye capable of penetrating a living cell [6]. Upon entering the cell, Rhodamine-6G binds to the inner membranes of mitochondria. Based on these observations, it has been proposed that Rhodamine dyes may be used for producing fluorescent images of mitochondria with low background noise and high resolution $[7,8]$. However, it became clear soon enough that such application is useful for in situ imaging, although is inacceptable for in vivo studies. In vivo, binding of Rhodamine dyes to the membranes of mitochondria decreases mitochondrial enzymatic activity, thus inhibiting the process of mitochondrial oxidative phosphorylation [6] and reducing the number of intact, metabolically active mitochondria within the cell [9]. As a result, normal functioning of the respiratory chain is dramatically prohibited, and the cell may eventually become "suffocated" and destroyed. When applied at relatively high concentrations, Rhodamine$6 \mathrm{G}$ affects this way a variety of cell cultures, malignant or normal [9-11]. 
We therefore conducted a series of preliminary in vitro experiments with different concentrations of Rhodamine$6 \mathrm{G}$, applying the latter to various cultured malignant vs. normal cell populations. Surprisingly, at very low concentrations Rhodamine-6G was found to damage tumor cells only, whereas much higher concentrations were needed to exert any impact on non-malignant cells. In other words, extremely low concentrations of Rhodamine-6G appeared to selectively destroy malignant cells in culture, sparing the normal cell populations.

The present study was aimed at investigating the assumption that Rhodamine-6G may not only selectively destroy tumor cells in culture but also inhibit tumor progression when administered to tumor-transplanted animals.

\section{Materials and methods}

Cell cultures. Five randomly chosen tumor cell lines, B16-F10 (murine melanoma, cat. No. CRL-6475 ${ }^{\mathrm{TM}}$ ), MCF-7 (female breast cancer, cat. No. HTB-22 ${ }^{\mathrm{TM}}$ ), HCT-116 (colon cancer, cat. No. CCL-247 ${ }^{\mathrm{TM}}$ ), ACHN (human renal carcinoma, cat. No. CRL61 $1^{\mathrm{TM}}$ ), and SW-620 (colon cancer, cat. No. CCL$227^{\mathrm{TM}}$ ) were purchased in ATCC (American Type Culture Collection, USA) and subcultured as recommended by the ATCC technical services. In addition, primary cultures of murine tumor cells were obtained from subcutaneous tumors of mice transplanted with B16-F10 melanoma for studies unrelated to the present investigation. Five randomly chosen non-malignant cell cultures, namely human peripheral blood mononuclear cells (PBMC), human umbilical cord endothelial cells (HUVEC), rat renal epithelial cell (EC) line, murine renal mesangial cells (MC) and renal embryonic cells (REC) isolated from metanephric mesenchymal tissues, served as normal controls. All cells were sub-cultured and maintained using their specific selective media $[12,13]$. After 3 to 5 passages, each cell population was seeded into the wells of 6 well-tissue culture plates, $2 \times 10^{6}$ cells per well, using their specific culture media supplemented with fetal calf serum (FCS). The cells were maintained in an incubator at standard conditions $\left(37^{\circ} \mathrm{C}, 95 \%\right.$ humidity, laminar flow of air supplied with $5 \% \mathrm{CO}_{2}$ ).

Experimental protocols. Following $24 \mathrm{~h}$ of culture, the cells were separately exposed, in duplicates, to different concentrations of Rhodamine- $6 \mathrm{G}\left(10^{-12} \mathrm{M}\right.$ through $\left.10^{-2} \mathrm{M}\right)$ and pulsed with $25 \mu \mathrm{Ci} / \mathrm{ml}^{3}{ }^{3} \mathrm{H}$-Thymidine. For each cell population, cells pulsed with ${ }^{3} \mathrm{H}$-Thymidine without being exposed to Rhodamine-6G served as normal controls. Following 48h, the cells were repeatedly washed with phosphate buffered saline ( $\mathrm{PBS}, \mathrm{pH}=7.4$ ), to wash out the excessive radioactive material. The cell samples were then separately transferred into polystyrene vials containing $4 \mathrm{ml}$ scintillation liquid. Radioactive counts were performed in a $\beta$-counter (LKB, USA), and the results subsequently calculated as mean CPM (radioactive counts per minute). The concentration of $10^{-6} \mathrm{M}$ Rhodamine-6G was then chosen as optimal, to be used in further experimentations.
Malignant cells and normal control cultures were seeded in equal (protein adjusted) cell amounts into 6-well tissue culture plates. The cells were pulsed with $25 \mu \mathrm{Ci} / \mathrm{ml}^{3}{ }^{3} \mathrm{H}$-Thymidine and immediately treated with Rhodamine-6G at the fixed concentration of $10^{-6} \mathrm{M}$ for $24 \mathrm{~h}, 48 \mathrm{~h}, 72 \mathrm{~h}$ or 5 days $(120 \mathrm{~h})$. Following $24 \mathrm{~h}, 48 \mathrm{~h}, 72 \mathrm{~h}$ or 5 days, the excessive radioactive material was washed out with PBS. The cell samples were transferred into polystyrene vials containing $4 \mathrm{ml}$ scintillation liquid, and their radioactivity counted in a $\beta$-counter. Total cell protein was assessed by Bradford's assay. The results were subsequently presented graphically as CPM per mg cell sample protein.

Animals. C56Bl male mice were purchased at Harlan Laboratories (Ness-Ziona, Israel) and maintained at standard conditions at Assaf Harofeh Medical Center animal facilities, to be used in the present experiment at age of 3 months \pm 1 week and weight $25 \pm 5 \mathrm{~g}$. The study received approval of the local Ethics Committee on Animal Experimentations and was conducted according to the National Institutes of Health Guidelines for the Care and Use of Laboratory Animals. The investigation has been sponsored by Anisopharm Investment Company, LTD (Israel).

Tumor implantation. B16-F10 cells destined for tumor implantations were collected, repeatedly washed in PBS $(\mathrm{pH}=7.4)$ and counted. Cell viability was assessed by $0.1 \%$ eosin exclusion. Only cultures with viability more than $95 \%$ were used in this study. The animals were injected subcutaneously with the B16-F10 melanoma cell aliquots, each prepared in a $0.2 \mathrm{ml}$ bolus containing $1.5 \times 10^{6}$ cells. Cell suspensions for injections were prepared in PBS. Control mice were injected subcutaneously with $0.2 \mathrm{ml}$ of PBS containing no malignant cells.

The majority of tumor-implanted animals developed tumors within $7 \pm 2$ days after injection. Six animals that failed to develop tumors on time were excluded from the study. At day 8 after tumor implantation, the animals were randomly divided into groups as designated in the Experimental design.

Experimental design. The study comprised 21 groups of C53Bl mice, $\mathrm{n}=12$ in each.

Control animal groups

Group1 (positive controls): Healthy animals not implanted with tumor cells, receiving injections of PBS solution in a 0.3 $\mathrm{ml}$ bolus, either once or twice a week.

Group 2 (negative controls): Tumor implanted animals not receiving the Rhodamine-6G treatment but, instead of the Rhodamine-6G, injected with PBS solution in a $0.3 \mathrm{ml}$ bolus, either once or twice a week.

Establishing the optimal Rhodamine-6G dose for a single injection

Groups 3-11, subgroups 3a-11a ( $n=6)$ : Tumor-implanted mice, receiving subcutaneous injections of Rhodamine-6G close to the site of the tumor, in a $0.3 \mathrm{ml}$ bolus once-a-week, at concentrations of $10^{-10} \mathrm{M}, 10^{-9} \mathrm{M}, 10^{-8} \mathrm{M}, 10^{-7} \mathrm{M}, 10^{-6} \mathrm{M}, 10^{-5} \mathrm{M}$, $10^{-4} \mathrm{M}, 10^{-3} \mathrm{M}$ and $10^{-2} \mathrm{M}$, respectively. 
Searching for the possible adverse effects of Rhodamine- $6 G$ injections to healthy non-malignant animals

Groups 3-11, subgroups 3b-11b (n=6): Non-malignant mice receiving, in parallel to subgroups $3 \mathrm{a}-11 \mathrm{a}$, subcutaneous injections of Rhodamine- $6 \mathrm{G}$ in a $0.3 \mathrm{ml}$ bolus, at concentrations of $10^{-10} \mathrm{M}, 10^{-9} \mathrm{M}, 10^{-8} \mathrm{M}, 10^{-7} \mathrm{M}, 10^{-6} \mathrm{M}, 10^{-5} \mathrm{M}, 10^{-4} \mathrm{M}, 10^{-3} \mathrm{M}$ and $10^{-2} \mathrm{M}$, respectively.

Based on the obtained results, concentrations of $10^{-6} \mathrm{M}, 10$ ${ }^{7} \mathrm{M}$ and $10^{-8} \mathrm{M}$ Rhodamine- $6 \mathrm{G}$ were chosen for conducting the next stage of experiments.

Establishing the optimal frequency of Rhodamine- $6 \mathrm{G}$ treatments

Groups 12-14: Tumor-transplanted mice receiving subcutaneous injections of Rhodamine- $6 \mathrm{G}$ in a $0.3 \mathrm{ml}$ bolus, at a concentration of $10^{-6} \mathrm{M}, 10^{-7} \mathrm{M}$ or $10^{-8} \mathrm{M}$ Rhodamine- $6 \mathrm{G}$, once-a-week.

Groups 15-17: Tumor-transplanted mice receiving Rhodamine-6G at a concentration of $10^{-6} \mathrm{M}, 10^{-7} \mathrm{M}$ or $10^{-8} \mathrm{M}$ Rhodamine-6G, twice-a-week.

The death of the last animal from group 2 (negative controls) served the end point for this part of experiment. Based on the obtained results, twice-a-week injections of $10^{-6} \mathrm{M}$ Rhodamine-6G were used in the next set of experiments.

Establishing the optimal time regimen for Rhodamine- $6 G$ injections

This part of the study was aimed to test the possible advantages of preventive therapy with Rhodamine-6G.

Group 18: Tumor-transplanted mice, regularly injected with $10^{-6} \mathrm{M}$ Rhodamine-6G twice-a-week, starting one week prior to tumor cell transplantation (-7 days).

Group 19: Tumor-transplanted mice, regularly injected with $10^{-6} \mathrm{M}$ Rhodamine-6G twice-a-week, starting concomitantly with tumor cell transplantation (0 days).

Group 20: Tumor-transplanted mice, regularly injected with $10^{-6} \mathrm{M}$ Rhodamine-6G twice-a-week, starting one week post tumor cell transplantation ( +7 days).

Group 21: Tumor-transplanted mice, regularly injected with $10^{-6} \mathrm{M}$ Rhodamine-6G twice-a-week, starting two weeks post tumor cell transplantation $(+14$ days).

Evaluation of clinical status, tumor progression, total body weight and survival rates of the experimental animals. Clinical status of each animal and tumor development by palpation were evaluated once-a-week based on the Good Research Practices (GRP) standard procedures recommended by McGill University Animal Care Committee and local Institutional Animal Care and Use Committee (IACUC). The end point of each weekly evaluation was the definition of each animal as normal, weak or dead.

Each animal was weighted prior to starting the study (the baseline) and once-a-week thereafter.

Tumor volume gain was assessed twice-a-week. The shape of subcutaneous tumors is assumed to be a three-dimensional hemi-ellipsoid $[14,15]$. Hence, in our study we calculated the tumor volumes by a typical three-dimensional formula for ellipsoid-like tumor volume evaluation: $\mathrm{V}=\pi: \mathbf{6} \times \mathbf{L} \times \mathrm{W}$ $\mathbf{x} \mathbf{H}$. The results were confirmed by applying the two-dimensional formula for evaluation of the same tumor volumes, recently proposed by Feldman et al [16]: $\mathrm{V}=\pi \mathbf{~} \mathbf{6} \times \boldsymbol{f}(\mathrm{L}$ $\mathbf{x ~ W})^{3 / 2}$. In both equations, the abbreviations are as follows: $\mathrm{L}$ - tumor length $(\mathrm{cm}), \mathrm{W}$ - tumor width $(\mathrm{cm}), \mathrm{H}$ - tumor height $(\mathrm{cm}), \mathrm{V}$ - tumor volume $\left(\mathrm{cm}^{3}\right)$. Comparison of tumor volume estimation by two different formulae demonstrated no significant differences between the two different methods of calculation.

The deaths of the animals within each experimental group were registered every other day. The death of the last animal within the negative control group served the end point of each part of the experiment. The rates of survival were calculated as percentages of total amount of the animals starting the experiment. The last remaining alive animal from each relevant group was sacrificed. The abdomens were opened, in order to count the visible metastatic tumors on the vital organs.

Statistical analysis. Statistical analysis was performed using SPSS-version 13 software. Statistical differences between the groups were evaluated by one way-ANOVA. Bonferroni test was applied for post-hoc analysis. Differences yielding $\mathrm{p}<0.05$ were considered statistically significant.

\section{Results}

In vitro experiments. Serially taken microphotographs (Fig. 1A through $1 \mathrm{H}$ ), the results of time-dependent (Fig. 2A) and dose-dependent (Fig. 2B) decrease of ${ }^{3} \mathrm{H}$-Thymidine incorporation, as well as percentages of malignant vs. non-malignant cell survival at fixed optimal time and dosage regimen of Rhodamine-6G treatment (Fig.3), collectively demonstrated significant inhibition of proliferation and degeneration of cell monolayer confluence in all tumor cell cultures following exposure to Rhodamine-6G.

Compared to the confluent, undamaged monolayers of untreated tumor cell cultures (Fig. 1A-D), microscopic examination of the same malignant cells following treatment with Rhodamine-6G revealed massive cell disruption and absence of monolayer confluence, significantly decreased cell count and visible necrotic, autophagic and/or apoptotic appearance of the remaining cells (Fig. 1E-H).

The rate of destruction of malignant cells by Rhodamine-6G significantly depended on the time of exposure to the latter (Fig. 2A). At the first $24 \mathrm{~h}$ of culture it also appeared to be concentration-dependent, since at this time point inhibition of cell proliferation was found maximal at $10^{-2} \mathrm{M}$ and minimal at $10^{-12} \mathrm{M}$ Rhodamine-6G concentrations (Fig. $2 \mathrm{~B}$ ), prompting us to choose the $10^{-6} \mathrm{M}$ concentration as the optimal for our further experiments. However, following 5 days of treatment even the cultures exposed to the lowest concentrations of Rhodamine- $6 \mathrm{G}$ were found completely destroyed, proving that in the long run the effect of Rhodamine-6G depends only on the time elapsing (Fig. 2A).

At the fixed time point and concentration, Rhodamine6G successfully prevented ${ }^{3} \mathrm{H}$-Thymidine incorporation, i.e. 

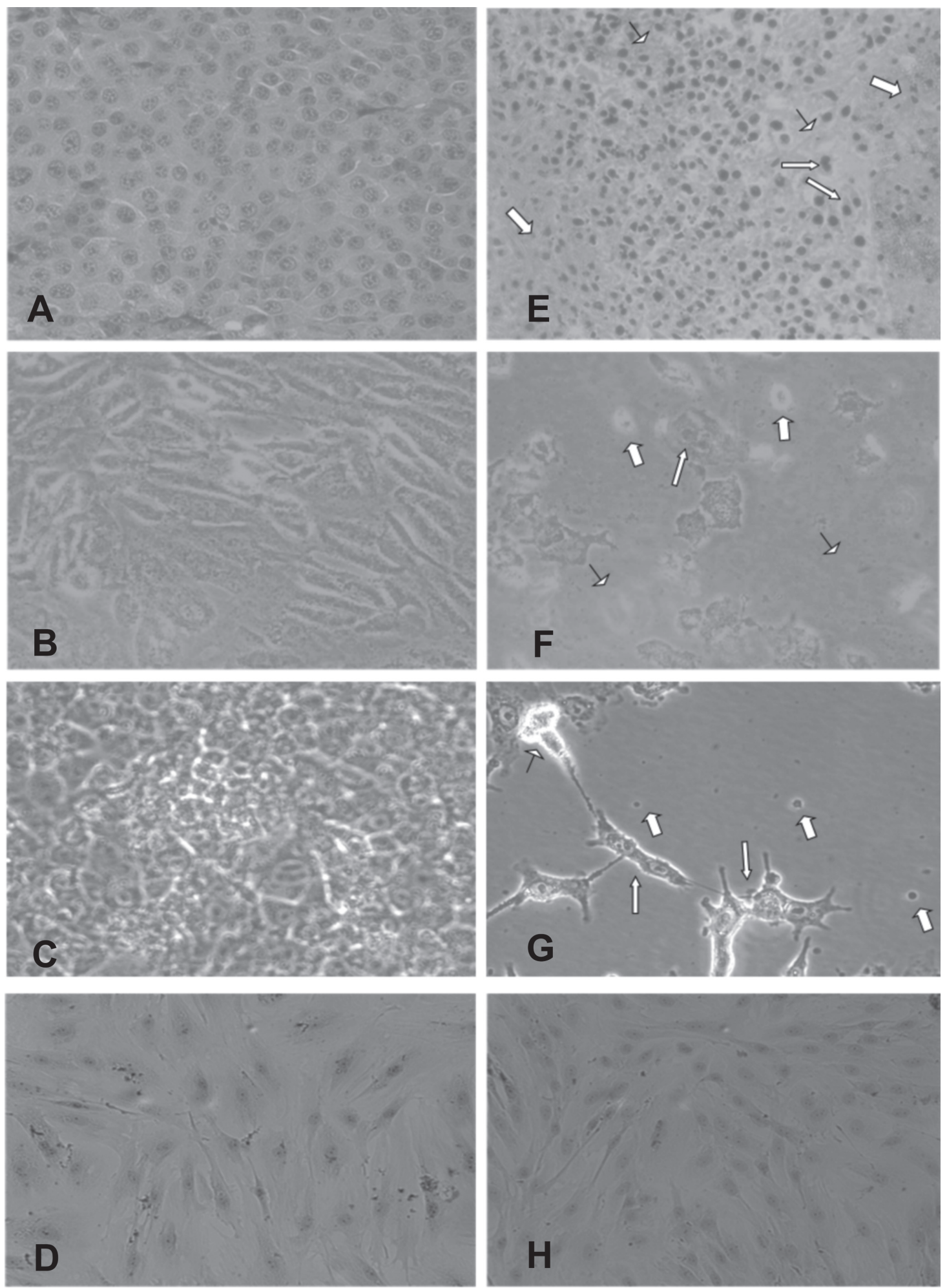

Figure 1A-C: malignant cell lines (B16-F10, ACHN and HCT, respectively) not exposed to Rhodamine-6G.

Figure 1D: normal REC not exposed to Rhodamine-6G.

Figure 1E-G: malignant cell lines (B16-F10, ACHN and HCT, respectively) treated with $10^{-6} \mathrm{M}$ Rhodamine-6G for $72 \mathrm{~h}$.

Figure 1H: normal REC treated with $10^{-6} \mathrm{M}$ Rhodamine-6G for $72 \mathrm{~h}$.

Abbreviations: B16-F10 - murine melanoma cells; ACHN - renal carcinoma cells; HCT - colon cancer cells; REC - renal embryonic cells. Arrows: thin arrows - apoptotic cells; thick arrows - apoptotic bodies; pin-head arrows - necrotic cells. 

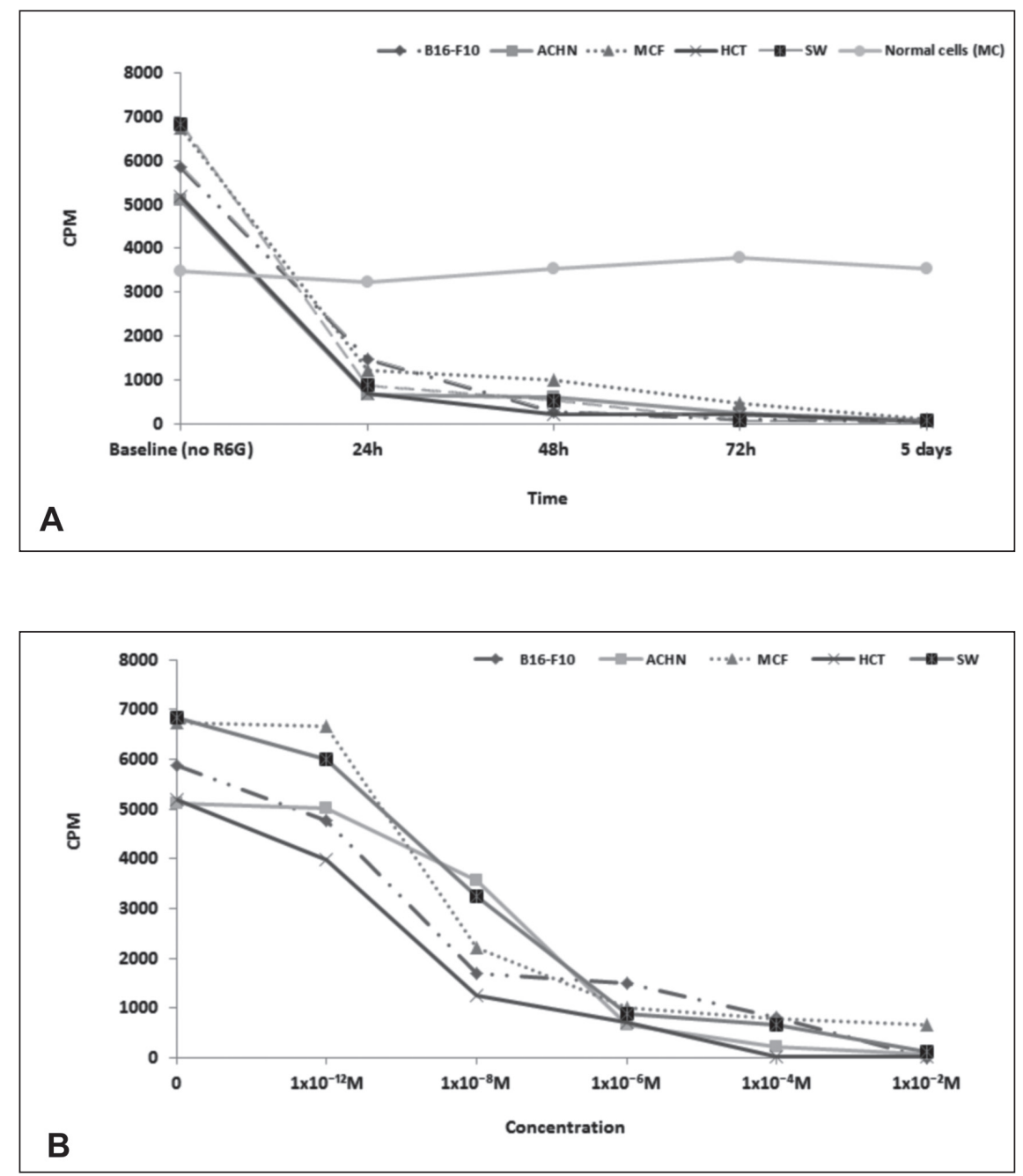

Figure 2A: Inhibition of ${ }^{3} \mathrm{H}$-Thymidine incorporation in various cultured tumor cell lines by incubation with $10^{-6} \mathrm{M}$ Rhodamine-6G for different time periods: time-response curve.

Figure 2B: Inhibition of ${ }^{3} \mathrm{H}$-Thymidine incorporation in various tumor cell lines by incubation with Rhodamine-6G at different concentrations: doseresponse curve.

Abbreviations: B16-F10 - murine melanoma cells; ACHN - renal carcinoma cells; MCF - breast cancer cells; HCT - colon cancer cells; SW - colon cancer cells; MC - murine renal mesangial cells; CPM - radioactive counts per minute; R6G - Rhodamine-6G.

decreased the rate of survival of all tested human and rodent tumor cell cultures. Percent of surviving malignant cells varied from $15 \%$ to $17 \%$ for different tumors (Fig. 3). The most prominent results of inhibition of malignant cell survival were obtained with B16-F10 murine melanoma, be the latter originating from tumors of $\mathrm{C} 57 \mathrm{Bl}$ mice or from commercial cell line.

When applied to normal control cultures, be they human or rodent, $10^{-6} \mathrm{M}$ concentration of Rhodamine- $6 \mathrm{G}$ resulted in a negligible inhibition of their survival rates: $90 \%-95 \%$ of these cell cultures were not affected by Rhodamine-6G (Fig.3).

In vivo experiment: Evaluation of tumor development, metastatic dissemination, clinical status and weight loss.
The majority of tumor-transplanted mice demonstrated palpable subcutaneous tumor outgrowths within a week after the injection of B16-F10 melanoma cells. Negative controls (tumor-implanted animals not treated with Rhodamine-6G) developed tumors reaching $320 \pm 10 \mathrm{~mm}^{3}$ volume within 22 \pm 2 days after transplantation (Fig.4), whereas mice treated with Rhodamine-6G demonstrated dose-dependent delay of tumor volume gain. At the end of this part of the experiment, i.e. death of the last animal from the untreated negative control group, tumor volumes of animals receiving $10^{-6} \mathrm{M}$ or $10^{-7} \mathrm{M}$ Rhodamine-6G were around $200 \pm 8 \mathrm{~mm}^{3}$ (Fig. 4 , $\mathrm{p}<0.001$ compared to the untreated malignant controls).

The main results of animal clinical evaluation at the last week of the experiment are summarized in Table 1. As can 


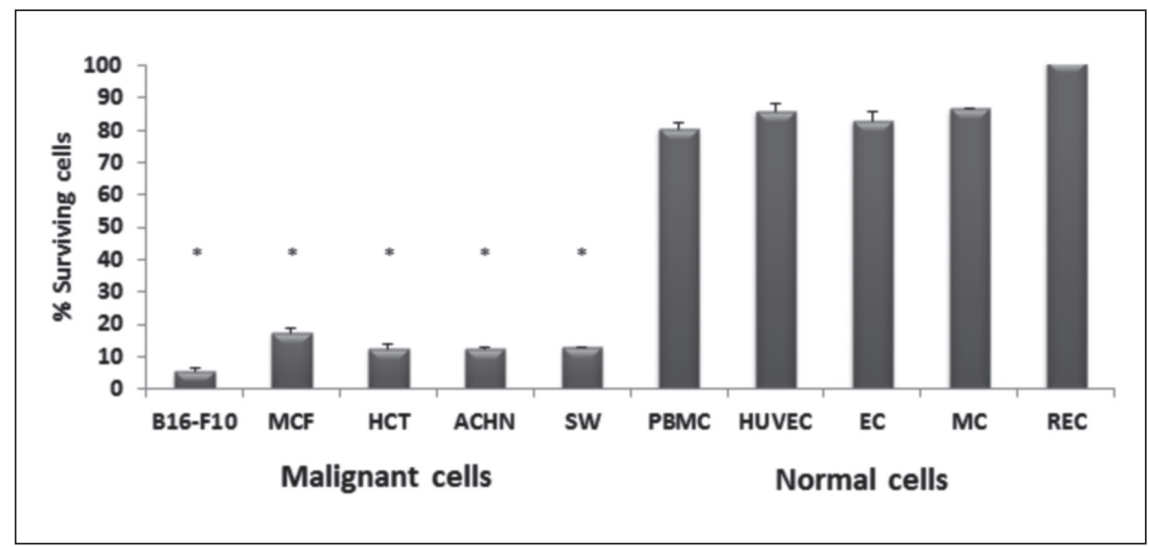

Figure 3. Percent survival of different malignant cells vs. non-malignant controls following incubation with $10^{-6} \mathrm{M}$ Rhodamine-6G.

The experiment lasted for 5 days. Percent of surviving cells was checked daily. The results are obtained at day 5 .

* - Significantly different from normal control cultures ( $\mathrm{p}<0.001$ for each comparison).

Abbreviations: B16-F10 - murine melanoma; MCF - breast cancer; HCT - colon cancer; ACHN - renal carcinoma; SW - colon cancer; PBMC - peripheral blood mononuclear cells; HUVEC - human umbilical cord endothelial cells; EC - rat renal epithelial cells; MC - murine renal mesangial cells; REC - normal renal embryonic cells.

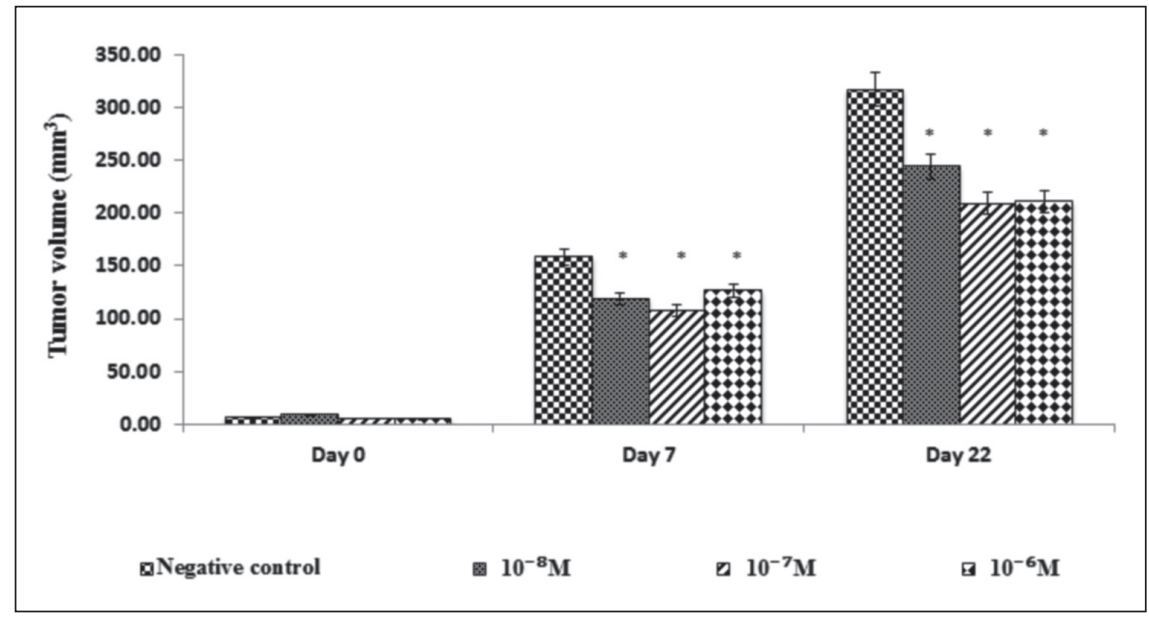

Figure 4. Dynamics of tumor growth in response to different concentrations of Rhodamine-6G (the dose-response curve).

Day 0 through Day 22 - the number of days that passed following tumor implantation;

Negative control - tumor-implanted animals untreated with Rhodamine-6G;

* - significantly different from the respective values of negative controls ( $p<0.001$ for each comparison).

$10^{-8} \mathrm{M}$ through $10^{-6} \mathrm{M}$ - Rhodamine-6 G concentrations used in this part of the experiment.

be seen, negative controls (tumor-implanted mice untreated with Rhodamine-6G) acquired "unkempt" fur, loss of appetite accompanied by increased water consumption and either aggressive or depressed behavior. They experienced loss of mobility, their movements became uneven and eyes were closed most of the time, collectively indicating the presence of neurologic disturbances.

By contrast to negative controls, experimental groups of tumor-implanted mice treated with Rhodamine-6G were found in a better clinical condition. More so, animals receiving two weekly doses of Rhodamine-6G, exhibited significantly improved clinical parameters compared to their respective counterparts receiving only one weekly dose. The difference was specifically demonstrable during the last week of the study (Table 1).

Tumor-transplanted mice receiving injections of $10^{-6} \mathrm{M}, 10^{-}$ ${ }^{7} \mathrm{M}$ or $10^{-8} \mathrm{M}$ Rhodamine-6G twice-a-week had better exterior appearance compared not only to the negative controls but also to the experimental groups under other treatment regimens. Animals receiving $10^{-6} \mathrm{M}$ Rhodamine-6G twice-a-week demonstrated appearance, behavior and clinical condition closely resembling positive controls (Table 1). 
Table 1. Clinical parameters of the animals recorded during the last week of the experiment

\begin{tabular}{|c|c|c|c|c|c|c|}
\hline Group & Appearance & Attitude & Appetite & Thirst & Urination & Defecation \\
\hline 1 (Positive control) & $\begin{array}{c}\text { Normal fur, opened eyes, } \\
\text { normal mobility }\end{array}$ & Normal & Normal & Normal & $\begin{array}{c}\text { Normal } \\
(2 \pm 1 \mathrm{ml} / \text { day })\end{array}$ & $\begin{array}{c}\text { Normal } \\
\text { (Solid stool) }\end{array}$ \\
\hline 2 (Negative control) & $\begin{array}{l}\text { Unkempt fur, loss of } \\
\text { mobility, closed eyes }\end{array}$ & $\begin{array}{l}\text { Aggressive or } \\
\text { depressed }\end{array}$ & Lost & Increased & $\begin{array}{l}\text { Decreased } \\
(<1 \mathrm{ml} / \text { day })\end{array}$ & $\begin{array}{c}\text { Abnormal } \\
\text { (Liquid stool) }\end{array}$ \\
\hline $12\left(10^{-6} \mathrm{M}\right.$, once-a-week $)$ & $\begin{array}{l}\text { Better fur, partially loss } \\
\text { of mobility }\end{array}$ & $\begin{array}{l}\text { Indifferent } \\
\text { or depressed }\end{array}$ & $\begin{array}{l}\text { Partially } \\
\text { lost }\end{array}$ & Increased & $\begin{array}{c}\text { Normal } \\
(2 \pm 1 \mathrm{ml} / \text { day })\end{array}$ & $\begin{array}{c}\text { Normal } \\
\text { (Solid stool) }\end{array}$ \\
\hline $13\left(10^{-7} \mathrm{M}\right.$, once-a-week $)$ & $\begin{array}{l}\text { Better fur, loss of } \\
\text { mobility, closed eyes }\end{array}$ & $\begin{array}{l}\text { Depressed, } \\
\text { nonaggressive }\end{array}$ & Lost & Increased & $\begin{array}{l}\text { Decreased } \\
(<1 \mathrm{ml} / \text { day })\end{array}$ & $\begin{array}{c}\text { Abnormal } \\
\text { (Liquid stool) }\end{array}$ \\
\hline $14\left(10^{-8} \mathrm{M}\right.$, once-a-week $)$ & $\begin{array}{c}\text { Better fur, loss of } \\
\text { mobility, closed eyes }\end{array}$ & $\begin{array}{c}\text { Depressed, } \\
\text { nonaggressive }\end{array}$ & Lost & Increased & $\begin{array}{l}\text { Decreased } \\
(<1 \mathrm{ml} / \text { day })\end{array}$ & $\begin{array}{c}\text { Abnormal } \\
\text { (Liquid stool) }\end{array}$ \\
\hline $15\left(10^{-6} \mathrm{M}\right.$, twice-a-week $)$ & $\begin{array}{c}\text { Normal fur, almost } \\
\text { normal mobility, opened } \\
\text { eyes }\end{array}$ & $\begin{array}{l}\text { Not different from } \\
\text { positive } \\
\text { control }\end{array}$ & $\begin{array}{l}\text { Close to } \\
\text { normal }\end{array}$ & $\begin{array}{l}\text { Close to } \\
\text { normal }\end{array}$ & $\begin{array}{c}\text { Normal } \\
(2 \pm 1 \mathrm{ml} / \text { day })\end{array}$ & $\begin{array}{c}\text { Normal } \\
\text { (Solid stool) }\end{array}$ \\
\hline $16\left(10^{-7} \mathrm{M}\right.$, twice-a-week $)$ & $\begin{array}{l}\text { Better fur, partial loss of } \\
\text { mobility, closed eyes }\end{array}$ & $\begin{array}{l}\text { Indifferent, } \\
\text { nonaggressive }\end{array}$ & Lost & Increased & $\begin{array}{l}\text { Decreased } \\
(<2 \mathrm{ml} / \text { day })\end{array}$ & $\begin{array}{c}\text { Abnormal } \\
\text { (Liquid stool) }\end{array}$ \\
\hline $17\left(10^{-8} \mathrm{M}\right.$, twice-a-week $)$ & $\begin{array}{l}\text { Better fur, partial loss of } \\
\text { mobility, closed eyes }\end{array}$ & $\begin{array}{l}\text { Indifferent, } \\
\text { nonaggressive }\end{array}$ & Lost & Increased & $\begin{array}{l}\text { Decreased } \\
(<2 \mathrm{ml} / \text { day })\end{array}$ & $\begin{array}{c}\text { Abnormal } \\
\text { (Liquid stool) }\end{array}$ \\
\hline
\end{tabular}

Table 2. Total weekly weight gain (in gram) of mice subjected to Rhodamine-6G treatment

\begin{tabular}{|c|c|c|c|c|c|c|}
\hline Group & Baseline weight & $\begin{array}{c}\text { Week } 1 \\
\text { post tumor } \\
\text { implantation }\end{array}$ & $\begin{array}{c}\text { Week } 2 \\
\text { post tumor } \\
\text { implantation }\end{array}$ & $\begin{array}{c}\text { Week } 3 \\
\text { post tumor } \\
\text { implantation }\end{array}$ & $\begin{array}{c}\text { Week } 4 \\
\text { post tumor } \\
\text { implantation }\end{array}$ & $\begin{array}{c}\text { Week } 5 \\
\text { post tumor } \\
\text { implantation }\end{array}$ \\
\hline 1 (Positive control) & $23.9 \pm 0.6$ & $24.9 \pm 0.3$ & $25.5 \pm 0.4$ & $26.3 \pm 0.5$ & $27.2 \pm 0.4$ & $27.3 \pm 0.3$ \\
\hline 2 (Negative control) & $23.9 \pm 0.8$ & $23.7 \pm 0.5$ & $24.9 \pm 0.6$ & $25.5 \pm 0.4$ & $26.4 \pm 0.1$ & $26.6 \pm 0.2$ \\
\hline $12\left(10^{-6} \mathrm{M}\right.$, once-a-week $)$ & $23.7 \pm 0.4$ & $24.8 \pm 0.7$ & $26.8 \pm 0.6$ & $26.9 \pm 0.9$ & $26.9 \pm 0.4$ & $27.0 \pm 0.6$ \\
\hline $13\left(10^{-7} \mathrm{M}\right.$, once-a-week $)$ & $23.5 \pm 0.3$ & $25.1 \pm 0.4$ & $25.4 \pm 0.4$ & $26.3 \pm 0.6$ & $26.5 \pm 0.3$ & $27.4 \pm 0.5$ \\
\hline $14\left(10^{-8} \mathrm{M}\right.$, once-a-week $)$ & $23.4 \pm 0.4$ & $24.1 \pm 0.8$ & $25.9 \pm 0.6$ & $26.0 \pm 0.8$ & $26.3 \pm 0.3$ & $26.5 \pm 0.7$ \\
\hline 15 (10-6 M, twice-a-week) & $23.35 \pm 0.5$ & $25.2 \pm 0.7$ & $25.7 \pm 0.7$ & $26.8 \pm 0.8$ & $26.9 \pm 0.4$ & $27.3 \pm 0.4$ \\
\hline $16\left(10^{-7} \mathrm{M}\right.$, twice-a-week $)$ & $24.0 \pm 0.5$ & $24.7 \pm 0.5$ & $25.9 \pm 0.4$ & $26.7 \pm 0.5$ & $26.8 \pm 0.2$ & $27.0 \pm 0.8$ \\
\hline $17\left(10^{-8} \mathrm{M}\right.$, twice-a-week $)$ & $24.3 \pm 0.6$ & $23.5 \pm 0.9$ & $25.2 \pm 0.8$ & $25.9 \pm 0.4$ & $26.3 \pm 0.4$ & $26.8 \pm 0.8$ \\
\hline
\end{tabular}

The results of total mean weight change within each group during the experiment are presented in Table 2. During the entire experimental period, healthy animals from our positive control group demonstrated no significant weight fluctuations, with the exception of their natural, age-related, weight gain. All tumor-implanted mice demonstrated significantly decreased weight gain compared to their healthy counterparts, despite the fact that their weight loss was in part masked by the weight/volume gain of their growing tumors. At the end of the experiment, no statistically significant differences in total weight were observed either among the various experimental groups or between any experimental group and the negative control group. Most probably, this was due to the great individual variability in the appetite loss and decreased food consumption on the one side and the augmented thirst and increased water retention on the other side.

Fig. 5 shows the photographs of two randomly chosen animals, one from the negative control group (Fig. 5A) and the other from the tumor-implanted group treated with $10^{-6} \mathrm{M}$ Rhodamine-6G twice-a-week (Fig. 5B). The striking reduction of tumor appearance demonstrable by these photographs was, as already stated (Fig. 4), confirmed by the results of the tumor volume gain measurements.

Tumor-implanted mice, receiving injections of Rhodamine-6 6 at concentrations $10^{-6} \mathrm{M}$ through $10^{-8} \mathrm{M}$ twice-a-week, demonstrated statistically significant retardation of tumor growth (Fig. 4). Furthermore, all these groups showed statistically significant prolongation of survival.

Percent of surviving animals is presented in Fig. 6. As can be seen, during the experiment no deaths occurred in healthy controls (group A), whereas all the untreated controls (group B) were dead within 3 weeks following tumor implantation. In groups C, D and E, receiving Rhodamine-6G at concentrations $10^{-6} \mathrm{M}$ through $10^{-8} \mathrm{M}$ twice-a-week, part of the animals were yet alive at day 31 following tumor implantation. The best results were demonstrable in group $\mathrm{C}\left(10^{-6} \mathrm{M}\right.$ Rhodamine- $6 \mathrm{G}$ twice-a-week): $40 \%$ of the animals were alive at day 31 following tumor implantation.

When the last remaining animal from each relevant group was sacrificed, the abdomens opened for visualization of abdominal metastases and the subcutaneous tumors 

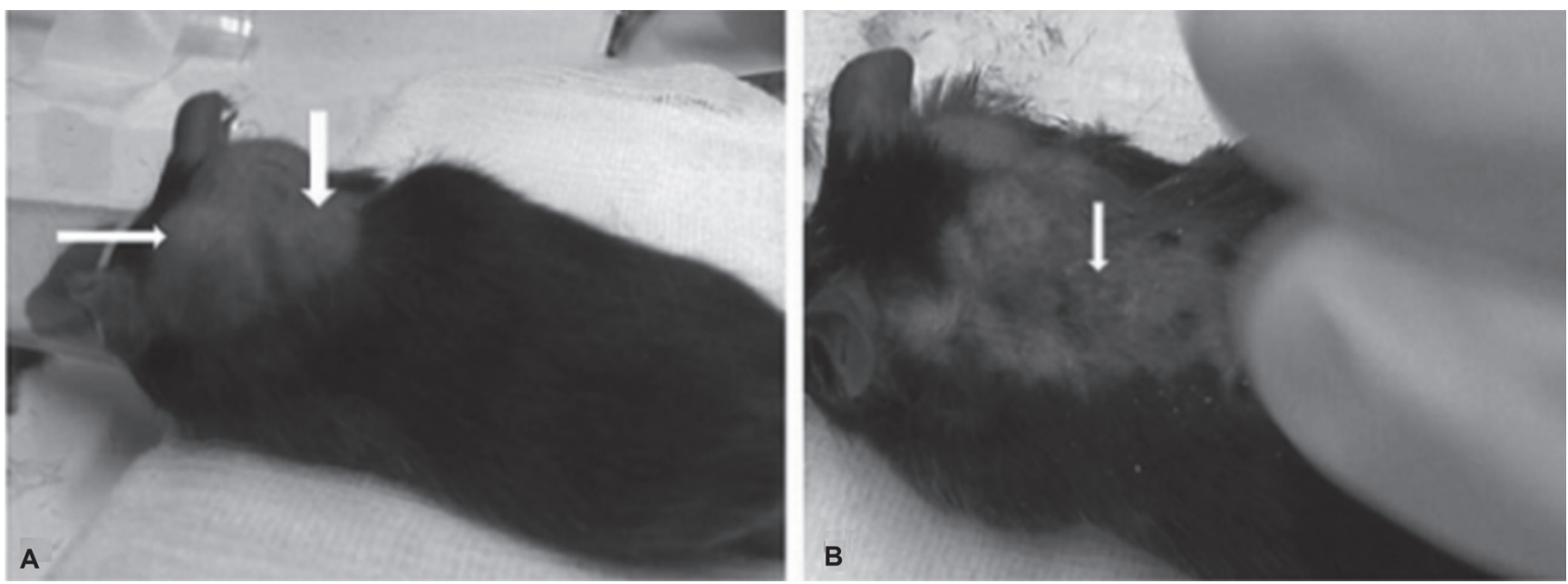

Figure 5. Differences in palpable tumor appearance (arrows) of a Rhodamine-6G untreated negative control mouse (Fig. 5A) and an animal treated with $10^{-6} \mathrm{M}$ Rhodamine-6G twice-a-week (Fig. 5B).

excised, extensive diffused necrotizing areas became evident within the excised tumor tissues of Rhodamine-6G treated animals. No such areas were observable in mice not receiving Rhodamine-6G. Solid capsules embodying the tumors of Rhodamine-6G untreated mice were found damaged or completely destroyed in mice subjected to Rhodamine-6G injections. Upon opening the abdomens, metastatic growths were observed mainly on lungs, livers, kidneys and duodenum of tumor-transplanted animals not receiving Rhodamine-6G. By contrast, the score of metastases in Rhodamine- $6 \mathrm{G}$ treated animals was negligible. No metastases were observed in animals treated with $10^{-6} \mathrm{M}$ Rhodamine-6G twice-a-week, collectively indicating the significant anti-metastatic properties of Rhodamine-6G treatment (Table 3). Animals receiving Rhodamine- $6 \mathrm{G}$ at concentrations significantly lower than $10^{-6} \mathrm{M}$ as well as those not treated with Rhodamine-6G at all, demonstrated intra-abdominal metastases, deteriorating clinical status and steeper mortality rate, most of them dying long before the termination of the experiment.

Safety studies on healthy animals. Healthy, non-malignant animals receiving injections of $10^{-8} \mathrm{M}, 10^{-7} \mathrm{M}$ and $10^{-6} \mathrm{M}$ Rhodamine-6G, expressed no adverse responses to treatment and did not differ from the untreated non-malignant positive controls in any respect. By contrast, healthy mice receiving Rhodamine-6G at concentrations higher than $10^{-5} \mathrm{M}$ showed dose-dependent signs of adverse reactions to the treatment. Healthy animals receiving the highest doses, namely $10^{-3} \mathrm{M}$ and $10^{-2} \mathrm{M}$ Rhodamine- $6 \mathrm{G}$ twice-a-week, demonstrated toxic effects within the first 3 out of 5 weeks of this part of the experiment (not shown).

Summary: the optimal regimen for Rhodamine-6G treatment. Survival, clinical status and inhibition of tumor

Table 3. Visual differences in tumor appearance and dissemination of metastases in mice subjected to Rhodamine-6G treatment

\begin{tabular}{|c|c|c|c|c|}
\hline Group & Palpation & $\begin{array}{c}\text { Protective capsule } \\
\text { embodying the tumor }\end{array}$ & $\begin{array}{l}\text { Tumor tissue } \\
\text { appearance }\end{array}$ & Metastases \\
\hline 1 (Positive control) & No tumor growth & None & None & None \\
\hline 2 (Negative control) & $\begin{array}{l}\text { Palpable, starting day 7; } \\
\text { relentlessly growing } \\
\text { thereafter }\end{array}$ & Thick, solid, undamaged & $\begin{array}{l}\text { Soft, lenient, relatively } \\
\text { uniform }\end{array}$ & $\begin{array}{c}+++++ \\
\text { (kidneys, lungs, liver, } \\
\text { diaphragm, duodenum) }\end{array}$ \\
\hline $12\left(10^{-6} \mathrm{M}\right.$, once-a-week $)$ & Small but still palpable & Significantly disrupted & $\begin{array}{l}\text { Non-uniform, extensively } \\
\text { diffused necrotizing areas }\end{array}$ & $\begin{array}{c}+ \\
\text { (lungs, liver) }\end{array}$ \\
\hline $13\left(10^{-7} \mathrm{M}\right.$, once-a-week $)$ & Small but still palpable & Significantly disrupted & $\begin{array}{c}\text { Non-uniform, diffused large } \\
\text { necrotizing areas }\end{array}$ & $\begin{array}{c}+ \\
\text { (lungs, liver) }\end{array}$ \\
\hline $14\left(10^{-8} \mathrm{M}\right.$, once-a-week $)$ & Small but still palpable & Partially disrupted & $\begin{array}{c}\text { Non-uniform, } \\
\text { diffused necrotizing areas }\end{array}$ & $\begin{array}{c}+ \\
\text { (kidneys, liver) }\end{array}$ \\
\hline 15 (10-6 M, twice-a-week) & Almost unpalpable & Profoundly disrupted & The entire tissue looks necrotic & None \\
\hline $16\left(10^{-7} \mathrm{M}\right.$, twice-a-week $)$ & Almost unpalpable & Profoundly disrupted & Large amounts of necrotizing tissue & None \\
\hline $17\left(10^{-8} \mathrm{M}\right.$, twice-a-week) & Almost unpalpable & Profoundly disrupted & Large amounts of necrotizing tissue & None \\
\hline
\end{tabular}




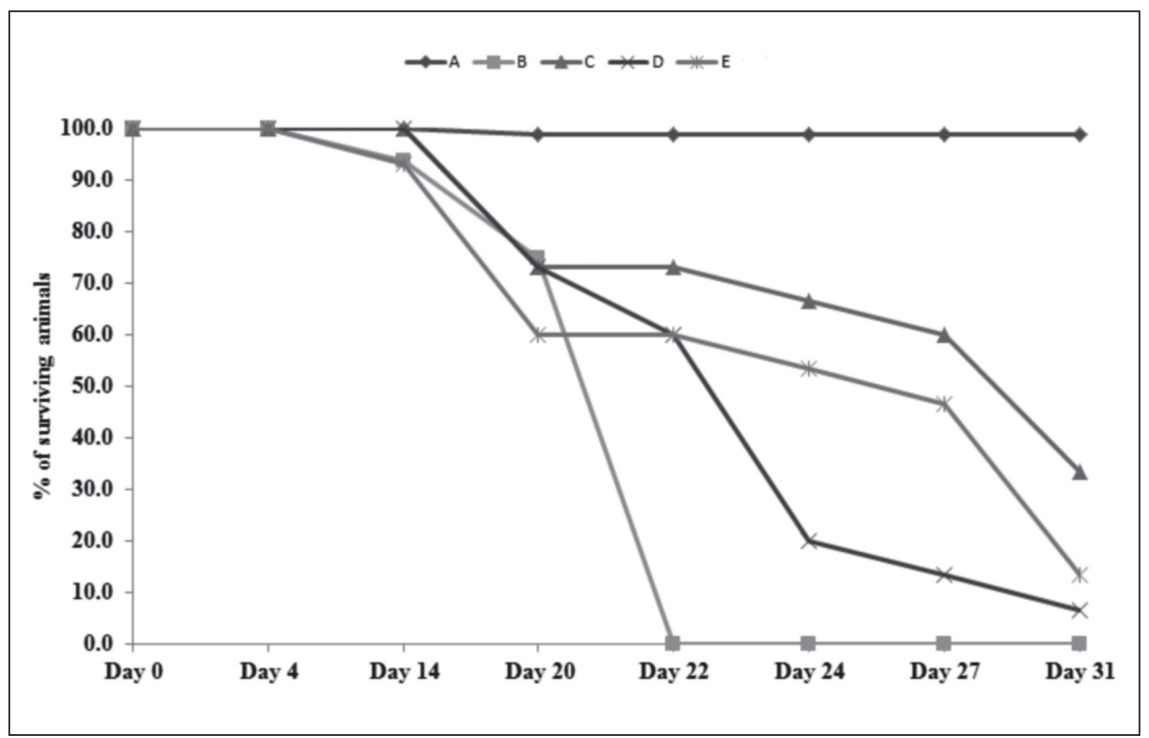

Figure 6. Survival rates of tumor-implanted animals treated with $10^{-6} \mathrm{M}$ Rhodamine-6 $\mathrm{G}$ twice-a-week.

Group A - positive control (healthy untreated mice); Group B - negative control (tumor-implanted mice untreated with Rhodamine-6G); Group $\mathrm{C}$ - tumor-implanted mice treated with $10^{-6} \mathrm{M}$ Rhodamine-6G twice-a-week; Group D - tumor-implanted mice treated with $10^{-7} \mathrm{M}$ Rhodamine-6G twice-a-week; Group E - tumor-implanted mice treated with $10^{-8} \mathrm{M}$ Rhodamine-6G twice-a-week.

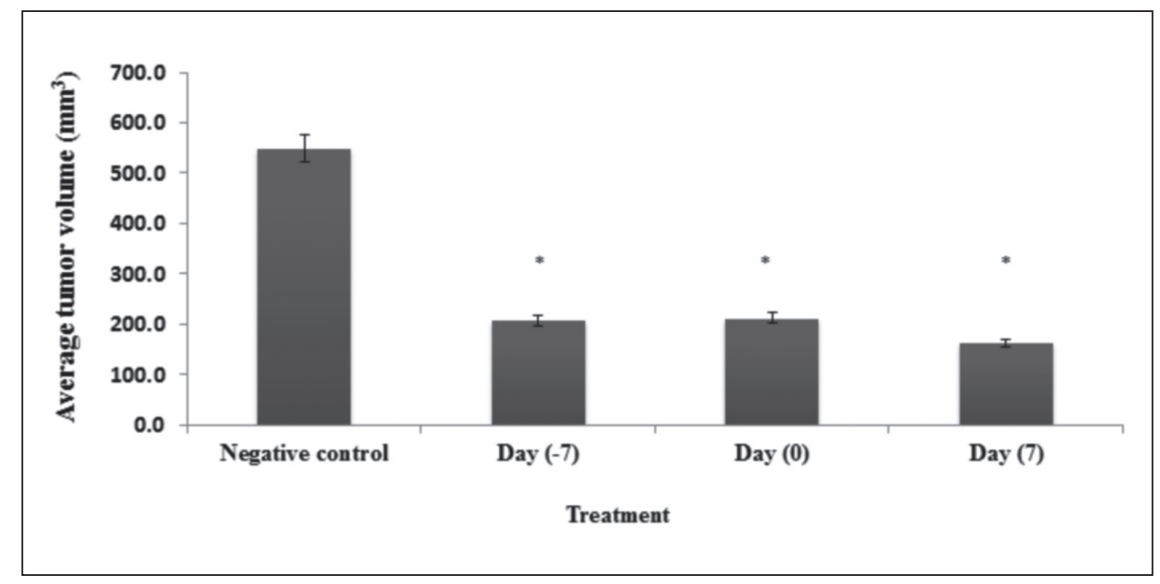

Figure 7. Effect of preventive vs. delayed start of treating the tumor-implanted animals with Rhodamine-6G.

The animals were treated with a fixed dose of Rhodamine- $6 \mathrm{G}\left(10^{-6} \mathrm{M}\right)$ twice-a-week. Rhodamine injections were started either one week prior to tumor implantation, concomitantly with tumor implantation or one week following the latter. Death of the last animal from the untreated control group was accepted as the end point of the experiment.

* - tumor volume significantly different from the respective value of negative control ( $p<0.001$ for each comparison);

Negative control - animals implanted with B16-F10 melanoma but untreated with Rhodamine-6G;

Day (-7) - Rhodamine-6G treatment started one week prior to tumor implantation;

Day (0) - Rhodamine-6G treatment started concomitantly with tumor implantation;

Day (7) - Rhodamine-6G treatment started one week following tumor implantation.

development were significantly improved in animals receiving two weekly injections of Rhodamine-6G compared to those receiving one weekly treatment. The most promising results were achieved with $10^{-6} \mathrm{M}$ Rhodamine-6G when, in addition to doubling the number of weekly injections, the preventive treatment was applied, i.e. when administration of two weekly injections started 7 days prior to the tumor transplantation procedure (Fig. 7). Summarizing all the above, $10^{-6} \mathrm{M}(1.1 \mu \mathrm{g} / \mathrm{kg}$ body weight $)$ dosage of Rhodamine$6 \mathrm{G}$ appeared to provide the optimal effect. Firstly, it yielded 
significant positive impact on survival, clinical status and inhibition of tumor development, including metastases dissemination. Secondly, the dosage was significantly lower than concentrations exerting toxic effects on healthy, nonmalignant animals.

\section{Discussion}

The results of the present investigation demonstrated that extremely low concentrations of Rhodamine-6G profoundly decreased survival and significantly suppressed proliferation of a variety of cultured human and rodent malignant cells. The same concentrations of Rhodamine-6G were far less potent in affecting viability and proliferation of various normal cell cultures. Furthermore, when low concentrations of Rhodamine-6G were injected to murine melanoma-transplanted C57Bl mice, they suppressed tumor growth and development, significantly prolonged survival, decreased spreading of metastases and improved vital clinical parameters.

Rhodamine-6G is a fluorescent organic dye well known for its antioxidant properties. Due to the relatively low molecular weight, Rhodamine-6G molecule is capable of penetrating the membrane of a living cell and binding to the inner membranes of mitochondria [9]. Hence, Rhodamine-6G has been used for diagnosing genetically inherited mitochondrial disorders [9], monitoring mitochondrial changes associated with malignant cell transformation [17] or, in vitro, in fluorescent staining for visualization of cultured normal or malignant cell lines [18-20]. Thus far, the members of Rhodamine family, including Rhodamine$6 \mathrm{G}$, have been demonstrated to destroy various cell cultures when applied to the latter in high concentrations [9-11]. In a number of studies which happened to use lower concentrations of Rhodamine the latter was shown to selectively affect tumor cells by destruction of mitochondria via binding to their membranes [19-24]. It has been then suggested that Rhodamine might be selectively toxic towards at least some malignant cells in vitro [21-24]. Among various explanations, it has been proposed that the mechanisms accounting for such selectivity might be the differences in the plasma membrane potential between normal and carcinoma cells [21].

Rhodamine concentrations used in the above mentioned studies were relatively high (about $0.8-1.0 \mathrm{mg} / \mathrm{ml}$ ), and in vitro were found deleterious not only to malignant cells, but also to normal cell cultures. Hence, not surprisingly, treatment of tumor-transplanted rodents with similar Rhodamine doses was associated with increasing host weight loss and mortality [11]. Taken collectively, this information, reported more than two decades ago but not explored further, prompted us to suggest that lowering the Rhodamine- $6 \mathrm{G}$ concentrations might serve the key for their selective, preferential destruction of tumor cells. The results of the present investigation confirmed this suggestion. In a nutshell, we were able to demonstrate that extremely low $\left(10^{-6} \mathrm{M}\right)$ concentrations of Rhodamine- $6 \mathrm{G}$ profoundly disrupted various tumor cell cultures. Their effect on normal adult cell populations was negligible. Moreover, when Rhodamine-6G was injected to melanoma-transplanted mice, their tumor progression was suppressed, survival and clinical condition improved, and spreading of metastases profoundly decreased. Applied at such low concentrations, Rhodamine-6G demonstrated its anti-cancer properties without exerting undesirable effects on healthy control animals. Much higher concentrations of Rhodamine-6G were needed to exert any adverse effects on healthy controls.

Besides cardinal surgery, the most efficient approach to cancer treatment remains the aggressive arrest of tumor development by means of chemotherapy. Unfortunately, cytotoxic agents routinely used for chemotherapy also non-selectively destroy the rest of the normal proliferating cells. Differential inhibition of tumor growth without damaging healthy tissues and organs of the patient would be the oncologist's "dream come true". However, any search for a selective cancer therapy method has to be based on some principal physiologic differences between malignant and normal cells. We suggest that exploring the unique pattern of energy metabolism in tumor cells may be a good starting point for research in this direction.

As already mentioned, Rhodamine dyes are capable of entering a living cell and attach to cell mitochondria. Malignant cells differ from a majority of normal cells by increased size albeit decreased number of mitochondria per cell and, consequently, by altered patterns of mitochondrial activities $[25,26]$. For any cell, malignant or normal, binding of Rhodamine- $6 \mathrm{G}$ to the inner membrane of a given mitochondria would decrease its enzymatic activity, inhibit ATP generation and thus reduce the total number of intact, metabolically active mitochondria per cell. Since the number of active mitochondria is a priori significantly reduced in a malignant cell, destruction of the same number mitochondria might become detrimental for metabolic activity of a malignant cell but not yet critical for a non-malignant cell. Hence, it seems quite plausible that treatment with low doses of Rhodamine-6G would reduce energy generation in mitochondria-deprived hypoxic tumor cells to a critical level, whereas the same reduction would be less, or not at all, effective in non-malignant cells. The total number of active mitochondria and the magnitude of their energy production would make the difference. In other words, much lower concentrations of Rhodamine-6G are needed to destroy tumor cells rendering the Warburg pattern of metabolism than to exert any appreciable effect on normal cells with normal mitochondrial numbers and normal oxygen turnover.

In summary, Rhodamine-6G has a potential to selectively suppress malignant cell growth in vitro and tumor progression in vivo. Rhodamine-6G treatment significantly prolongs survival of tumor-transplanted mice, improves their vital 
clinical parameters and substantially decreases dissemination of metastases. The same low concentrations of Rhodamine$6 \mathrm{G}$ exert no adverse effects when injected to healthy control animals.

We suggest that low concentrations of Rhodamine-6G effectively destroy hypoxic tumor cells with their already decreased mitochondrial count and activities. However, such low concentrations of Rhodamine-6G are harmless to normal body cells with high mitochondrial count, normal mitochondrial activities and regular oxygen turnover. Selective anti-tumor properties of low concentrations of Rhodamine-6G are based on the unique natural physiologic differences in energy turnover. Such unique pattern of energy metabolism is a common feature for all malignancies. One might suggest that in future studies low concentrations of Rhodamine-6G might be found useful not only in case of melanoma. If clinically relevant, low doses of Rhodamine-6G may have a potential to selectively inhibit tumor growth in cancer patients, limiting or, at least in some cases, avoiding the use of routinely prescribed highly toxic chemotherapeutic agents.

\section{References}

[1] WARBURG O, WIND F, NEGELEIN E. The metabolism of tumors in the body. J Gen Physiol 1927; 8: 519-530. http:// dx.doi.org/10.1085/igp.8.6.519

[2] WARBURG O. On respiratory impairment in cancer cells. Science 1956; 124: 269-270.

[3] PEDERSEN PL. Tumor mitochondria and the bioenergetics of cancer cells. Prog Exp Tumor Res 1978; 22: 190-274.

[4] UNWIN RD, CRAVEN RA, HARNDEN P, HANRAHAN S, TOTTY N et al. Proteomic changes in renal cancer and co-ordinate demonstration of both the glycolytic and mitochondrial aspects of the Warburg effect. Proteomics 2003; 3: 1620-1632. http://dx.doi.org/10.1002/pmic.200300464

[5] CHEN Y, CAIRNS R, PAPANDREOU I, KOONG A, DENKO NC. Oxygen consumption can regulate the growth of tumors, a new perspective on the Warburg effect. PLoS One 2009; 4: e7033. http://dx.doi.org/10.1371/journal. pone. 0007033

[6] GEAR AR. Rhodamine 6G. A potent inhibitor of mitochondrial oxidative phosphorylation. J Biol Chem 1974; 249: 3628-3637.

[7] NADAKAVUKAREN KK, NADAKAVUKAREN JJ, CHEN LB. Increased rhodamine 123 uptake by carcinoma cells. Cancer Res 1985; 45: 6093-6099.

[8] RONOT X, BENEL L, ADOLPHE M, MOUNOLOU JC. Mitochondrial analysis in living cells: the use of rhodamine 123 and flow cytometry. Biol Cell 1986; 57: 1-7. http://dx.doi. org/10.1111/j.1768-322X.1986.tb00458.x

[9] WILLIAMS AJ, MURRELL M, BRAMMAH S, MINCHENKO J, CHRISTODOULOU J. A novel system for assigning the mode of inheritance in mitochondrial disorders using cybrids and rhodamine 6G. Hum Mol Genet 1999; 8: 1691-1697. http://dx.doi.org/10.1093/hmg/8.9.1691
[10] GLEDHILL JR, WALKER JE. Inhibition sites in F1-ATPase from bovine heart mitochondria. Biochem J 2005; 386: 591-598. http://dx.doi.org/10.1042/BJ20041513

[11] FEARON KC, PLUMB JA, BURNS HJ, CALMAN KC. Reduction of the growth rate of the Walker 256 tumor in rats by rhodamine $6 \mathrm{G}$ together with hypoglycemia. Cancer Res 1987; 47: 3684-3687.

[12] EFRATI S, BERMAN S, GOLDFINGER N, EREZ N, AVER$\mathrm{BUKH} \mathrm{Z}$ et al. Enhanced angiotensin II production by renal mesangium is responsible for apoptosis/proliferation of endithelial and epithelial cells in a model of malignant hypertension. J Hypertens 2007; 25: 1041-1052. http://dx.doi. org/10.1097/HJH.0b013e32807fb09c

[13] EFRATI S, BERMAN S, TOV YS, AVERBUKH Z, WEISSGARTEN J. Hyperglycemia alters renal cell responsiveness to pressure in a model of malignant hypertension. J Hypertens 2009; 27: 365- 375. http://dx.doi.org/10.1097/ HJH.0b013e32831b46ab

[14] MAYR NA, TAOKA T, YUH WT, DENNING LM, ZHEN WK et al. Method and timing of tumor volume measurement for outcome prediction in cervical cancer using magnetic resonance imaging. Int J Radiat Oncol Biol Phys 2002; 52: 14-22. http://dx.doi.org/10.1016/S03603016(01)01808-9

[15] EGOROV V, AYRAPETYAN S, SARVAZYAN AP. Prostate mechanical imaging: 3-D image composition and feature calculations. IEEE Trans Med Imaging 2006; 25: 1329-1340. http://dx.doi.org/10.1109/TMI.2006.880667

[16] FELDMAN JP, GOLDWASSER R, MARK S, SHWARTZ J, ORION I. A mathematical model for tumor volume evaluation using two-dimensions. JAQM 2009; 4: 455-462.

[17] HORIKOSHI T, YOSHIOKA T, KUBOTA Y, YANAGISAWA K. Fluorescent dye monitoring of mitochondrial changes associated with malignant cell transformation. Cell Struct Funct 1987; 12: 525-537. http://dx.doi.org/10.1247/ csf. 12.525

[18] MATSUMOTO Y, SASAOKA N, TSUCHIDA T, FUJIWARA T, NAGAO $S$ et al. Fluorescent dye rhodamine $6 \mathrm{G}$ as a molecular probe to study drug resistance of C6 rat glioma cells. J Neurooncol 1992; 13: 217-222. http://dx.doi.org/10.1007/ BF00172473

[19] BEREITER-HAHN J, SEIPEL KH, VOTH M, PLOEM JS. Fluorimetry of mitochondria in cells vitally stained with DASPMI or rhodamine 6 GO. Cell Biochem Funct 1983; 1: 147-155. http://dx.doi.org/10.1002/cbf.290010306

[20] BERNS MW, SIEMENS AE, WALTER RJ. Mitochondrial fluorescence patterns in rhodamine 6G-stained myocardial cells in vitro. Analysis by real-time computer video microscopy and laser microspot excitation. Cell Biophys 1984; 6: 263-277.

[21] LAMPIDIS TJ, HASIN Y, WEISS MJ, CHEN LB. Selective killing of carcinoma cells „in vitro“ by lipophilic-cationic compounds: a cellular basis. Biomed Pharmacother 1985; 39: $220-226$.

[22] LAMPIDIS TJ, BERNAL SD, SUMMERHAYES IC, CHEN LB. Selective toxicity of rhodamine 123 in carcinoma cells in vitro. Cancer Res 1983; 43: 716-720. 
[23] BERNAL SD, LAMPIDIS TJ, MCISAAC RM, CHEN LB. Anticarcinoma activity in vivo of rhodamine 123, a mitochondrial-specific dye. Science 1983; 222: 169-172. http://dx.doi. org/10.1126/science.6623064

[24] BERNAL SD, LAMPIDIS TJ, SUMMERHAYES IC, CHEN LB. Rhodamine-123 selectively reduces clonal growth of carcinoma cells in vitro. Science 1982; 218: 1117-1119. http://dx.doi.org/10.1126/science.7146897
[25] MODICA-NAPOLITANO JS, STEELE GD JR, CHEN LB. Aberrant mitochondria in two human colon carcinoma cell lines. Cancer Res 1989; 49: 3369-3373.

[26] CHICHE J, ROULEAU M, GOUNON P, BRAHIMI-HORN MC, POUYSSEGUR J et al. Hypoxic enlarged mitochondria protect cancer cells from apoptotic stimuli. J Cell Physiol 2010; 222: 648-657. 